\title{
陸面輝度温度変動を考慮した \\ マイクロ波放射計による陸上降水有無判定 \\ IDENTIFICATION OF PRECIPITATION OVER LAND BY MICROWAVE RADIOMETER CONSIDERING THE VARIATION OF BRIGHTNESS TEMPERATURE OF LAND SURFACE
}

\author{
瀬戸心太 ${ }^{1}$ ・井口俊夫 ${ }^{2}$ \\ Shinta SETO and Toshio IGUCHI \\ 1正会員 博士 (工学) (独) 通信総合研究所（广184-8795 東京都小金井市貫井北町4-2-1） \\ 2 非会員 Ph. D (独) 通信総合研究所 （广184-8795 東京都小金井市貫井北町4-2-1）
}

\begin{abstract}
This study challenges identification of precipitation over land by microwave radiometer. For that purpose, we prepare database of land surface brightness temperature from 1998 to 2000 using TRMM (Tropical Rainfall Measuring Mission) /TMI (TRMM Microwave Imager) and PR (Precipitation Radar) data. PR data is used for precise identification of non-rainfall condition. These databases can represent inter-annual variation, seasonal variation, diurnal variation, heterogeneity within 1 degree grid, and variation caused by soil moisture.

Rainfall identification is done by comparing the deviation of observed brightness temperature from average and standard deviation of referred database with a negative threshold $k_{0}$. Only $85 \mathrm{GHz}$ observation can give comparable result with existing TMI algorithm (2A12) for all rain rate, but $37 \mathrm{GHz}$ observation can give as good performance as $85 \mathrm{GHz}$ observation in case of strong rainfall (more than $10 \mathrm{~mm} /$ hour). When diurnal variation or variation by soil wetness is considered, the performance of lower frequency observation is slightly improved.
\end{abstract}

Key Words : Microwave radiometer, precipitation, soil moisture, emission, scattering, Tropical Rainfall Measuring Mission (TRMM), Global Precipitation Measurement (GPM)

\section{1. 背景と目的}

陸上における降水観測の手段として，地上の雨量計や 降水レーダの観測網は地域的に限定されており，全球の 水資源評価などに必要なグローバルに均質な降水量プロ ダクトの作成には衛星によるリモートセンシング観測の 利用が欠かせない，降水観測に利用可能なリモートセン サには，降水レーダ，マイクロ波放射計，赤外放射計の 3 種類がある．衛星搭載の降水レーダは降水現象の鉛直 分布を直接観測できる長所があるが，観測幅が狭いため に時間的変動の激しい降水現象をとらえるのには不十分 な面がある. また，赤外放射計は静止気象衛星や極軌道 衛星に搭載されており観測頻度は高いが，観測される雲 の情報と地上の降水量は必ずしも直接的に結びつかない． マイクロ波放射計による観測は直接的には鉛直方向の解 像度を持たないものの, 雲粒ではなく降水粒子を観測で きることから，赤外放射計に比べると直接的な推定が可 能である. さらに, 降水レーダよりも観測頻度が高い.
このため，マイクロ波放射計は衛星による降水観測，と りわけ降水量プロダクトの作成において中心的に利用す ることが期待されている．2007年から始まる予定の全球 降水観測計画 (GPM)においては，各国の協力による8機 のマイクロ波放射計を利用して，3時間間隔の降水量プ ロダクトを作成することが計画されている.

マイクロ波放射計による降水量推定方法は，海上と陸 上で大きく異なっている，海上では，雨粒から射出され るマイクロ波の放射強度（輝度温度で表現される）と地 上の降水量の物理的な関係をもとにして降水量を推定し ている (吸収アルゴリズム ${ }^{1)}$ ) 。ところが，陸上の場合 には, 背景となる陸面自体の輝度温度が高いために, 雨 粒による輝度温度の増加がほとんど観測できない，そこ で, 降雨層の上層にある雪・氷粒子によってマイク口波 が散乱され，輝度温度が減少することを利用して，地上 の降水量を推定する (散乱アルゴリズム ${ }^{2)}$ )。散乱アル ゴリズムでは，雪・氷粒子による散乱と地上の降水量に は必ずしも直接的な関係がなく（降水の鉛直分布の特性 に依存するため)，高精度な推定は難しい，陸上の場合 
には，さらに，雪・承粒子による散乱のシグナルに対し てノイズとなる陸面の輝度温度の変動が大きいことが問 題となる. 陸面の輝度温度は, 植生や土壌の状態に影響 を受けるため, 海面に比べると空間的な変動が大きく, モデル化も困難とされている．これまで，陸面の輝度温 度の時空間変動について, 砂漠域や積雪面など極端に輝 度温度が低い状態については降水観測に与える影響が考 慮されている3),4). そのほかの一般的な変動の影響につ いては，チベット高原を対象に土壤水分量と降水量の同 時推定を行った研究5)があるが，全球的な統計としての 結果は出ていない. このため, 本研究では, 実際の衛星 による観測データから，陸面輝度温度についての統計的 なデータベースを作成して，これを利用した降水有無判 定手法を検討寸る，本論文では以下，熱帯降雨観測衛星 (TRMM) のデータを利用して, 陸面輝度温度についての データベースを作成する（2節）。次に, このデータ ベースを利用して陸面輝度温度の変動の特徴について解 析する（3節）。つづいて，データベースを参照した降 水有無判定試験を行う（4節）。

\section{2. 陸面輝度温度データベースの作成}

\section{（1）無降水時データの抽出}

衛星観測データから陸面輝度温度の情報を取り出すた めには，少なくとも無降水時に行われた観測を抽出する ことが必要である. 実際には, 晴天時であっても大気中 の水蒸気量などにより輝度温度が影響を受けるため, 陸 上で観測された輝度温度と陸面の輝度温度とは一致しな いが, 本研究の目的を考えた場合に大気の影響は 2 次的 なものとして無視することにする. TRMMに搭載されてい る降水レーダ $(\mathrm{PR})$ による降水有無判定を利用して無降水 時のマイクロ波放射計(TMI) の輝度温度データを取り出 すこととした．PRでは，海陸の影響をあまり受けずに観 測できるため，陸上においても信頼できる降水有無判定 が可能である. TRMMの公式プロダクトから，TMIの観測 輝度温度が収められた軌道データ (プロダクト名称1B11) とPRの降水・地表面フラグなどが収められた軌道データ （プロダクト名称2A21）を利用する. TMI は $10 \mathrm{GHz}$, $19 \mathrm{GHz}, 21 \mathrm{GHz}, 37 \mathrm{GHz}, 85 \mathrm{GHz}$ のつの周波数, 9 つのチャ ンネル（21GHzは垂直偏波のみ）を持つ。空間解像度は 周波数ごとに異なり，10GHzの場合に63.2km（スキャン垂 直方向 $) \times 36.8 \mathrm{~km}$ (スキャン方向 $)$ であるが, 周波数が高 いほど小さくなり，85GHzの場合には7. $2 \mathrm{~km} \times 4.6 \mathrm{~km}$ とな る. 一方, PRの空間分解能は $4.3 \mathrm{~km}$ と小さい. このため, 図-1に示寸ように, TMIの観測域の中に複数のPRの観測 が含まれることになる. プロダクト $2 \mathrm{~A} 21$ に収められてい るPRの降水フラグとしては"no rain", "rain possible", "rain certain"の 3 種類がある。 "rain possible"はノイズまたは極めて弱い雨であり輝度温度

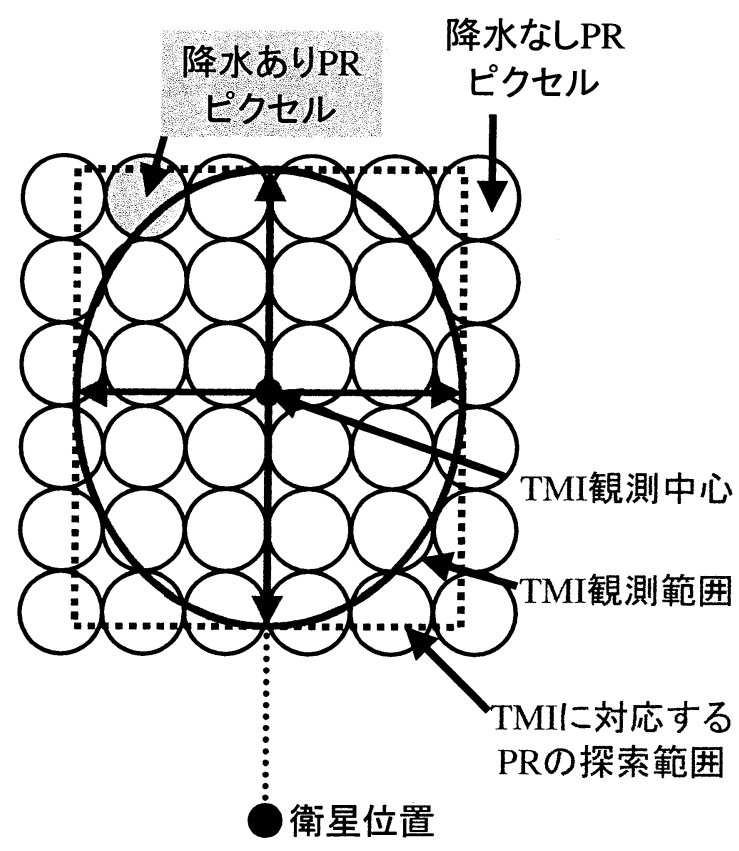

図-1 PRとTMIの観測を組み合わせた降水有無判定について の概念図. (この場合は降水ありと判定される)

に与える影響が小さいために，「降水なし」として扱う. ここでは”rain certain”と判定された場合のみ「降水あ

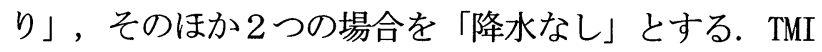
の周波数ごとの観測範囲を図-1の点線の枠に示すような 長方形領域で近似する. この長方形内に観測中心を持つ PRの観測のうちひとつでも「降水あり」のフラグを示寸 ものがあれば, TMIのその周波数での観測が降水の影響 を受けているものとみな寸. すべてのPRの観測が「降水 なし」の場合のみTMIの観測が無降水条件下で行われた と判定する. 同様に, 地表面タイプ (陸上, 海上, 沿岸 域）フラグについても、TMIの観測範井に含まれるPRが すべて陸上のフラグを示す場合のみTMIが陸上を観測し ているものとみなす.

\section{（2）データベースの種類}

次に陸面輝度温度の時空間変動の解析に利用しやすい 形にデータベースを作成する. 最初に, 基本となるデー タベース（「基本変動データベース」と呼ぶ）として, 空間解像度が緯度経度 $1^{\circ}$ ，時間解像度が 1 ヶ月のグ リッドデータを作成する. チャンネルごとに, 各グリッ ドに該当する無降水時・陸面での観測輝度温度の平均值 と標準偏差を計算する，1節で述べたように，陸面輝度 温度はさまざまなスケールでの時空間変動を示す。この ため, $1^{\circ}$ グリッド, 1 ヶ月より小さいスケールでの変 動についても考慮する必要がある. 陸面の輝度温度を変 動させる原因は大きく植生量・土壌水分量・物理温度に 分けられるが，このうち土壤水分量については降水イ心゙ ントに起因する 1 ケ月以下のスケールでの変動（季節内 変動）が大きく, さらに物理温度については日内変動が 
大きい. また, 空間的に $1^{\circ}$ グリッドの中に含まれる不 均一性についても考慮する必要がある.

これらのより細かな変動を考慮するために, 基本変動 データベースの条件に加えて, 空間解像度を $0.2^{\circ}$ グ リッドにした「空間変動データベース」，日内変動を考 慮して地方時刻（1 時間ごと）で分類した「日内変動 データベース」をそれぞれ作成することにした．さらに， 土㙵水分量などに起因する季節内変動を調べるために, 以下に説明する「水分変動データベース」を作成した.

マイクロ波放射計で観測した輝度温度から土猿水分量 を求めるための指標として, 小池ら $\left.{ }^{6}\right)$ は, ISWおよびPIの 組み合わせを提案している. ISW，PIはそれぞれ次のよ うに表現される.

$$
I S W=\frac{T_{B, \text { high }}-T_{B, \text { low }}}{\frac{1}{2}\left(T_{B, \text { high }}+T_{B, \text { low }}\right)}, P I=\frac{T_{B, v}-T_{B, h}}{\frac{1}{2}\left(T_{B, v}+T_{B, h}\right)}
$$

ただし, $T_{B}$ は輝度温度を, 添え字のhighは高周波数 チャンネルを, lowは低周波数チャンネルを, vは垂直偏 波を, hは水平偏波を表す。ここでは, ISW, PIを次のよ うに簡略化して利用する。

$$
I S W=T_{B, 37 h}-T_{B, 10 h}, P I=T_{B, 10 v}-T_{B, 10 h}
$$

ただし，37,10は周波数を表す. 各回の観測についての ISW, PIから，グリッドのISW, PIの平均值と標準偏差をも とにして，偏差をそれぞれ計算する．偏差が1以上， 0.5 以上, -0.5 以上, -1 以上, -1 以下で各 5 分類し, ISW, PIについての分類の組み合わせで25通りの分類を得る. 基本変動データベースの条件に，この条件を加えて分類 したものが「水分変動データベース」となる.

\section{3. 陸面輝度温度の変動と降水による影響}

\section{（1）各種変動の規模}

2 節で作成したデータベースをもとに, 各 $1^{\circ}$ グリッ ドについて, 季節変動, グリッド内不均一性, 日内変動, 水分量依存性を計算した．季節変動は，12ケ月分の基本 変動データベースを使い最大值と最小值の差で定義する. グリッド内不均一性は, 空間変動データベースの年平均 を用いて，25個のサブグリッドごとの最大值と最小值の 差で定義する. 同様に, 年平均した日内変動データベー ス，水分変動データベースを利用して，日内変動と水分 量依存性の大きさを定義する. その結果, 低緯度帯では 日内変動が強いが, 中緯度帯では季節変動が相対的に強 い，また，水分量依存性は，偏波間輝度温度差をとった 場合に大きく表れる. グリッド内の不均一性は, 砂漠域 で高く森林域で低い傾向を示すが，他の変動と比べて小 さい.

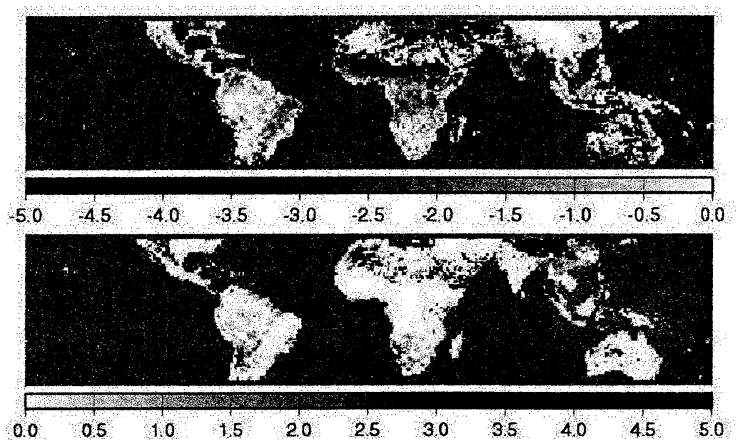

図-2 降水ありの輝度温度から降水なしの輝度温度を引 いた值(19GHzの垂直偏波; 1998-2000年の 3 年平均)。上の 図に負の場合，下の図に正の場合を示す領域を示す。

\section{（2）降水の影響}

次に，降水なしの場合の輝度温度と，降水ありの場合 の輝度温度を比較した. 後者は無降水と判定された以外 のすべての観測についての統計であり，さまざまな降水 量・降水タイプのものが含まれる. ほとんどのチャンネ ル・地域について, 降水ありの場合に輝度温度が低くな り，降水の影響は負のシグナルとして表れている. 海上 の場合に見られるような降水粒子からの射出による輝度 温度の増加は見られない，例外となるのは，チベット・ アンデスなどの積雪面である. 積雪面は, 海上と同様に 輝度温度が低いため, 降水による輝度温度の増加が見ら れる. 図-2に19GHz垂直偏波についての結果を示す。低 周波数では降水の影響は弱いがサヘル地帯やインドなど で比較的強い負のシグナルが表れている．このことにつ いては, 降水層の影響ではなく, 降水により一時的に土 壌水分量が増加した影響ではないかと推察できる.

本研究の目的である, 降水有無判定に対する陸面輝度 温度の変動の影響を調べるには, この節の (1) と (2)の結 果を比較することでも定性的に可能であるが，より定量 的な議論をおこなうために, 次節のような試験を行う.

\section{4. 降水有無判定試験}

\section{（1）方法}

観測された輝度温度 $T B_{o b s}$ に対して, 対応する陸面輝度 温度データベースの平均值 $\mu$ と標準偏差 $\sigma$ を参照し, 式 (3) から偏差 $k$ を計算する.

$$
k=\left(T B_{o b s}-\mu\right) / \sigma
$$

3 (2) で述べたように，陸上ではほとんどの場合に降水 のシグナルは輝度温度を減少させる方向に表れることか ら，kがある閾值 $k_{0}\left(k_{0}<0\right)$ より小さい場合に「降水あり」， それ以外の場合に「降水なし」と判定する. この結果を， PRの降水フラグによる判定を基淮として採点する. TRMM の公式プロダクトに含まれるTMIによる降水有無判定 


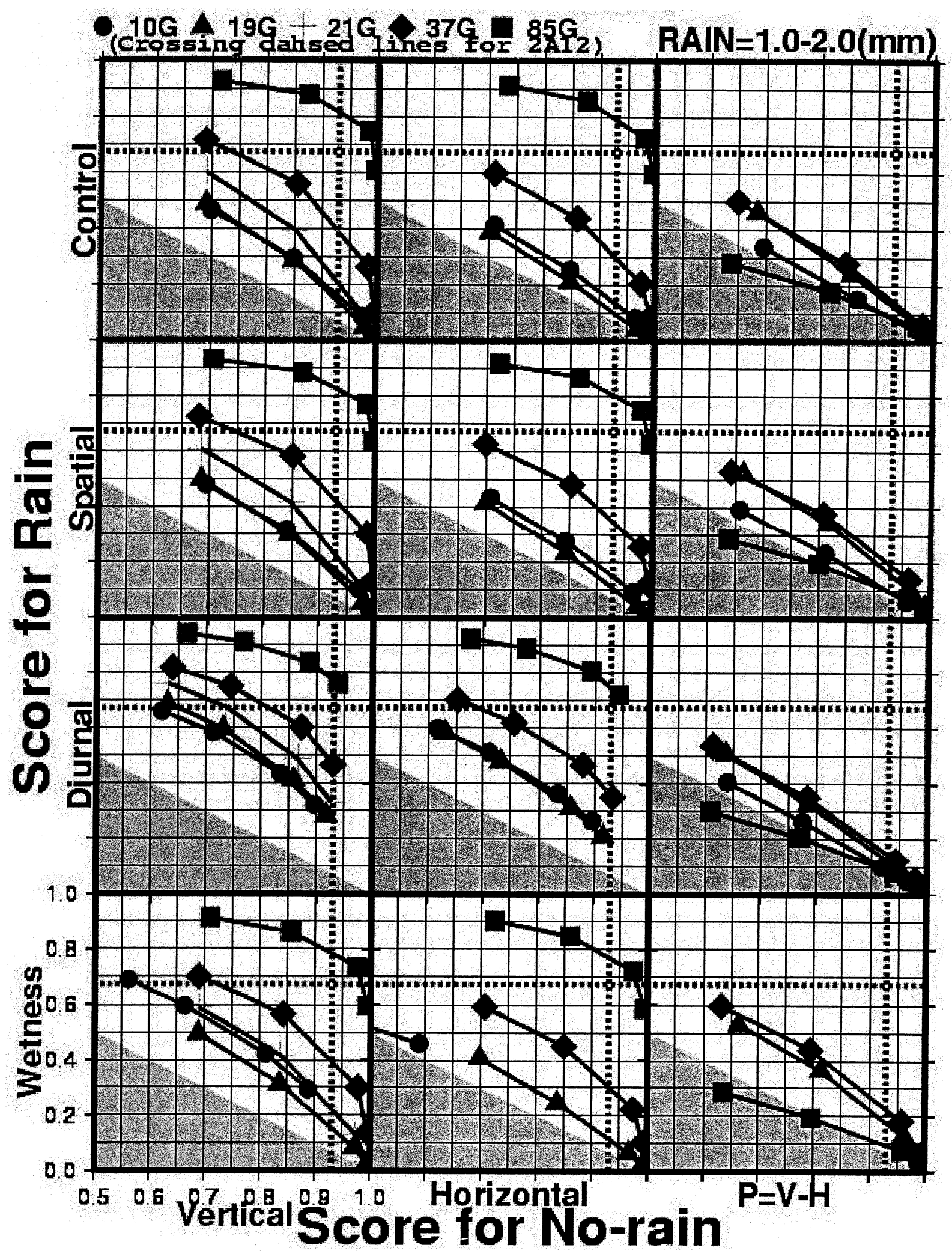

図-3 試験 1 についての降水あり正解率(横軸) と降水なし正解率(縦軸). 各周波数(各シンボルに対応), 偏波(図の各列に対 応，左から垂直偏波・水平偏波・偏波間輝度温度差), 参照するデータベース(図の各行に対応，上から基本变動・空間変動・ 日内変動・水分変動データベース), 閾值 $k_{0}$ (各線の左上から $\left.-0.5,-1,-2,-3\right)$ の值ごとに示す. 比較のため, 公式プロダクトの 正解率を示す(点線の交点). 左下の網掛け部は両正解率の合計が 1 に満たず，降水判定能力なしと考えられる部分.

（プロダクト2A12）に対しても，同様にPRを基準として 採点を行い, 本研究の結果と比較した. 公式プロダクト
では, 85GHzの偏光度を利用した判定が行われている. 2001年 7 月分の降水有無判定を，1998年から2000年まで 
の 3 年間を平均した 7 月の各種データベースをそれぞれ 参照して, 行った (試験 1 ) 。次に, 2000 年の 1 年分に ついて, 試験期間と同じ月の過去 2 年間 $(1998,1999$ 年) 平均で作成した基本変動データベースを参照して，降水 有無判定試験を行った（試験 2）。

\section{(2) 結果}

\section{a) 周波数・偏波による違い}

図-3に，試験 1 で基本変動データベースを参照した場 合の結果について示す．図-3には，参照するデータベー ス 4 種類と利用する偏波 3 種類の違いにより合計 12 個の 小図が示されている．各小図の横軸はPRが降水なしと判 定したスナップショットに対して，TMIが降水なしと判 定した場合を正解としてその割合（以下，「降水なし正 解率」）を，縦軸には同椂に定義される「降水あり正解 率」を示す．それぞれの線は，利用した周波数に対応す る. 各線上の点は $k_{\bar{o}}=-0.5,-1,-2,-3$ の場合にそれぞれ相 当する． $k_{0}$ を大きくとれば降水あり正解率が上がるが 降水なし正解率が下がり，一方 $k_{0}$ をさくとれば降水な し正解率が上がるが降水あり正解率が下がる。このため, 両正解率のバランスを保つ妥当な閾值の值 $k_{0}$ の選択が必 要である. $2 A 12$ 正解率を上回るのは85GHzの場合だけ であり，その場合の $k_{0}$ としては-2程度が妥当であった. 垂直偏波の場合，水平偏波よりもわずかに正解率がよい， また，偏波間輝度温度差の利用では，十分な正解率を上 げることができなかった。

b）参照するデータベースによる違い

低い周波数側の垂直偏波または水平偏波では，日内変 動データベースを利用することで正解率が向上する(図一 4). 同じ $k_{0}$ の值を利用した場合について，降水なしの正 解率はやや落ちるが，降水ありの正解率が高くなり，全 体としては改善されている. 降水なしの正解率が悪化す る理由としては，日内変動データベース自体の経年変化 の影響が考えられる. 試しに, 試験期間と同じ2001年7 月のデータベースを使うと，降水なしの正解率がほとん ど下がらないまま，降水あり正解率が大きく向上する. また，水分変動データベースを利用すると，低周波数帯 では正解率が向上寸ることが確認される。これは，低周 波数帯ほど土袞水分量の影響を受けやすいためと考えら れる. 高周波数のチャンネルについては, 各種データ ベースによる違いはほとんどない，空間変動データベー スを利用した効果はすべてのチャンネルを通じてほとん どなかった。

\section{c) 降水量別の正解率}

試験 1 について，降水あり正解率をPRによる降水量ご とに区分して集計した(図-5)。ここで降水量はTMIの $10 \mathrm{GHz}$ の観測範囲内に含まれるPRが観測した地表面付近 降水量（プロダクト $2 \mathrm{~A} 25$ より）の平均值である. $85 \mathrm{GHz}$ を利用寸ると，極めて弱い降水（降水量 $0.1 \mathrm{~mm} / \mathrm{hour}$ 未 満）から，TMIは統計的に反応できることが確認される.

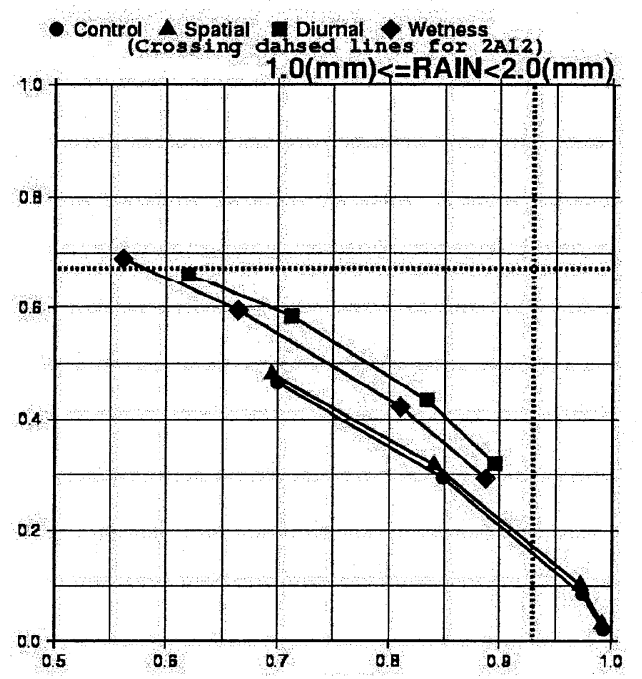

図-4 試験 1 について，参照するデータベースを変えた場 合の正解率の比較(10GHz垂直偏波の場合)．横軸が降水な し，縦軸が降水ありに対する正解率．凡例は左から順に基 本変動，空間変動，日内変動，水分変動に対応.

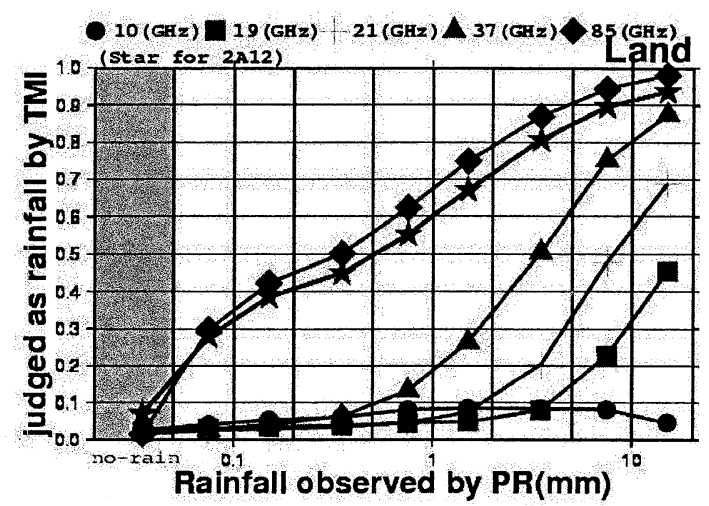

図-5 試験 1 について，降水あり正解率の降水量による変 化（各周波数の垂直偏波について表示）。左端（網掛け 部）は降水なしに対する誤答率.

ここで，統計的に反応しているとは，「降水なし」につ いてTMIが降水ありと判定した割合 (誤答率)よりも明ら かに高い正解率を示していることである。 一方， $37 \mathrm{GHz}$ を利用した場合には $1 \mathrm{~mm} /$ hour以上， $21 \mathrm{GHz}$ 利用した場 合には $2 \mathrm{~mm} / \mathrm{hour}$ 以上， $19 \mathrm{GHz}$ を利用した場合には $5 \mathrm{~mm} /$ hour以上の降水に対して統計的な反応が見られるが, 10GHzを利用した場合には $10 \mathrm{~mm} /$ hour以上でも反応が見ら れなかった。 $10 \mathrm{~mm} /$ hour以上の強い降水に対しては, 37GHzでも85GHzに近い正解率を得た。

d）正解率の季節変化 · 分布

次に試験 2 につい, 降水あり正解率の季節変化を示 す(図-6). 中緯度帯(緯度 $30^{\circ}$ 以上)については，南半 球・北半球いずれの場合にも, 夏の方が冬よりも正解率 が高い，この傾向は，85GHzの場合に顕著に表れる。な 
お，降水なしに対する誤答率はほとんど変化していな かった．また，試験 2 につて，2000年1年分を集計し た降水ありに対する正解率および降水なしに対する誤答 率の地域分布を示す (図-7)。その結果，低緯度帯におい て正解率が高いことが分かる．これらの理由として，冬 には積雪による影響が表れるほか，陸面輝度温度が高い 方が散乱のシグナルが得やすいことがあげられる.

\section{5. 結論}

陸上では，ほとんどの場合に，降水のある場合の方が 同じ地表面条件で降水のない場合に比べて，輝度温度が 下がる. このことは，降水粒子からの射出ではなく，降 水層の上層の雪・氷層による散乱によっていると考えら れる.このシグナルは，高周波数になるほど強くなるこ とと, 降水有無判定にノイズとなる陸面の輝度温度の変 動は低周波数の方が大きいことから，ほとんどの場合に 降水有無判定には85GHzのみが有効である. しかし, $10 \mathrm{~mm} / \mathrm{hour}$ 以上の強い降水に対しては $37 \mathrm{GHz}$ でも $85 \mathrm{GHz}$ と 同程度の判定精度を示すなど，強い降水に対しては低周 波数側のチャンネルもあわせて利用可能と考えられる. 低周波数側での観測については，物理温度の日内変動や 土壌水分量の変動の影響を受けることから，これらを考 慮した陸面輝度温度データベースを利用することで，降 水有無判定精度を改良することが可能である.

謝辞 : 本研究は, 科学技術振興事業団 戦略的創造研究 推進事業「衛星による高精度高分解能全球降水マップの 作成（代表 : 岡本謙一）」の成果の一部である. 同プロ ジェクトの参加者の皆様からは有益な指摘を多くいただ きました.ここに感謝いたします。

\section{参考文献}

1) Wilheit, T. T., A. T. C. Chang, M. S. V. Rao, E. B. Rodgers, and J. S. Theon.: A Satellite Technique for Quantitatively Mapping Rainfall Rates over the Oceans, Journal of Applied Meteorology, Vol.16, pp551-560, 1977.

2) Spencer, R. W., H. M. Goodman, and R. E. Hood.: Precipitation Retrieval over Land and Ocean with the SSM/I: Identification and Characteristics of the Scattering Signal. Joumal of Atmospheric and Oceanic Technology, Vol.6, pp254-273, 1991.

3) Grody, N. C.: Classification of Snow Cover and Precipitation Using the Special Sensor Microwave Imager. Journal of Geophysical Research, Vol96, pp7423-7435, 1991.

4) Ferraro, R. R., N. C. Grody, and G. F. Marks.: Effects of Surface Conditions on Rain Identification Using the DMSP-SSM/I. Remote Sensing Reviews, vol.11, pp195-209, 1994.

5) Fujii, H. and T. Koike.: Development of a TRMM/TMI Algorithm for Precipitation in the Tibetan Plateau by Considering Effects of

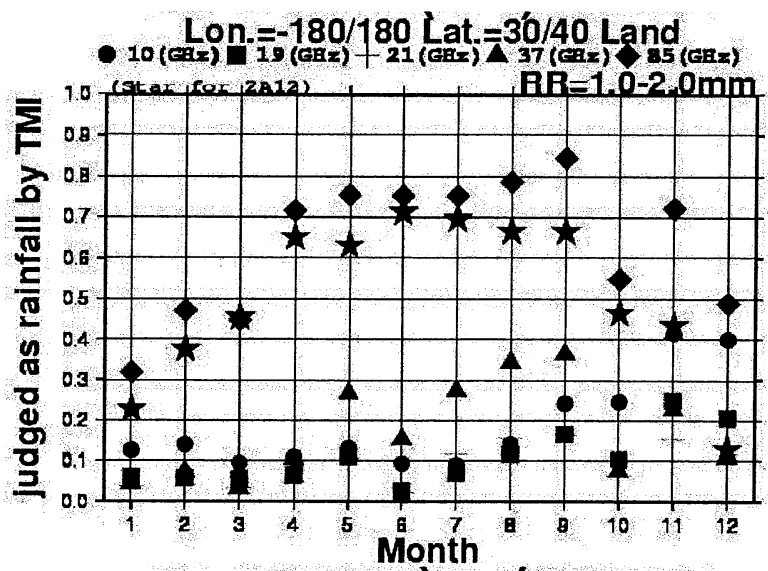

Lon $=-180 / 180$ Lat. $=-40 /-30$ Land

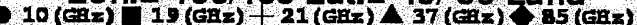

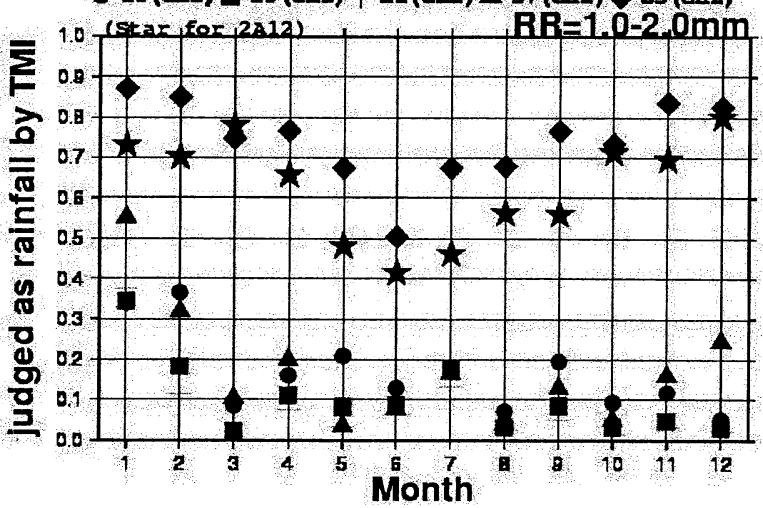

図-6 試験 2 について, 降水あり (降水量1.0-2.0m/hour) に対する正解率の季節変化（垂直偏波の各周波数について 表示) .上の図は北緯 $30^{\circ}$ 以北，下の図は南緯 $30^{\circ}$ 以南に ついての集計結果.

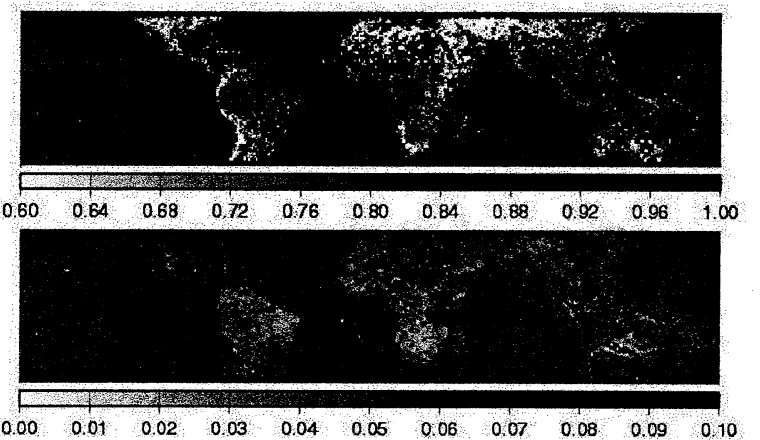

図-7 試験 2 について，年平均の正解率分布. 上の図は降 水あり (1.0-2.0 mm/hour) に対する正解率．下の図は，降水 なしに対する誤答率.

Land Surface Emissivity. Journal of the Meteorological Society of Japan, Vol.79, pp475-483, 2001.

6) 小池俊雄, 下茂 力, 太田 哲, 藤井秀幸, 柴田 彰.：陸 面水文量分布のグローバル推定のためのマイクロ波放射計ア ルゴリズムの開発と検証, 水工学論文集, Vol. 44, pp247$252,2000$.

（2003.9. 30受付） 